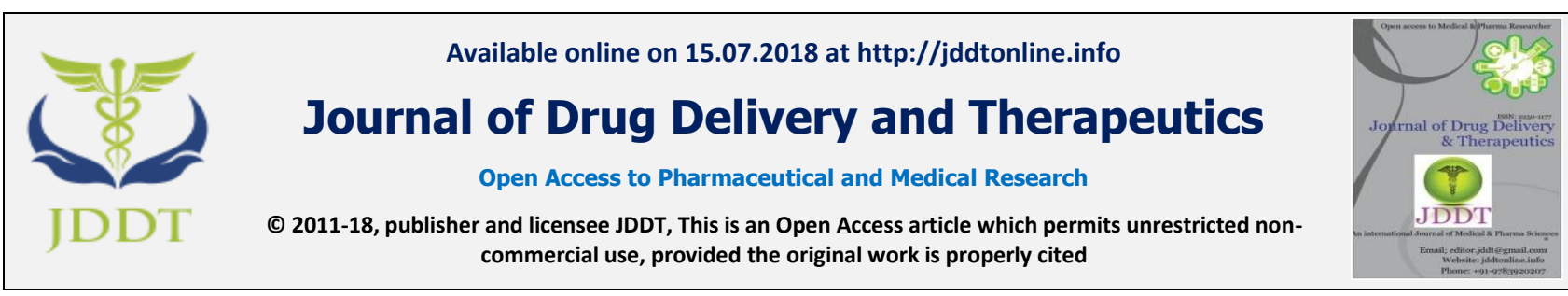

Open $\odot$ Access

Research Article

\title{
Preliminary phytochemical analysis, antimicrobial and antioxidant activity of Smilax zeylanica L. (Smilacaceae)
}

\author{
Dhanya Shree V.S., Arbin Ayesha, Saema Noorain G.K., Sahana B.K., Prashith Kekuda T.R* \\ Department of Microbiology, S.R.N.M.N College of Applied Sciences, N.E.S campus, Balraj Urs Road, Shivamogga-577201, \\ Karnataka, India
}

\section{ABSTRACT}

Objectives: Smilax zeylanica L. is a large, dioecious, scandent climbing shrub and an important medicinal plant belonging to the family Smilacaceae. The present study evaluates antimicrobial and antioxidant potential of leaf and fruit extracts of Smilax zeylanica L. (Smilacaceae).

Methods: Extraction of powdered leaf and fruit materials was carried out by maceration process using methanol. Phytochemical analysis of extracts was carried out by standard tests. Antibacterial and antifungal activity was evaluated by Agar well diffusion and Poisoned food technique respectively. Antioxidant activity was evaluated by DPPH free radical scavenging assay and Ferric reducing assay.

Results: Preliminary phytochemical analysis revealed the presence of alkaloids, flavonoids, tannins, triterpenoids and sterols in both leaf and fruit extracts. Leaf extract was shown to display marked antibacterial activity than fruit extract. Highest and least susceptibility to extracts was observed in case of Bacillus cereus and Salmonella typhimurium respectively. Leaf extract caused highest inhibition of test fungi than fruit extract. Susceptibility to extracts was greater in case of Bipolaris species than Aspergillus niger. Both leaf and fruit extracts scavenged DPPH radicals and exhibited ferric reducing potential in a dose dependent fashion. Leaf extract scavenged DPPH radicals more efficiently with $\mathrm{IC}_{50}$ value $20.80 \mu \mathrm{g} / \mathrm{ml}$ than fruit extract $\left(\mathrm{IC}_{50}\right.$ value $\left.35.85 \mu \mathrm{g} / \mathrm{ml}\right)$.

Conclusion: Leaf and fruit extracts of $S$. zeylanica were shown to exhibit antimicrobial and antioxidant activity which may be attributed to the presence of secondary metabolites such as alkaloids, flavonoids, tannins, triterpenoids and sterols. Further studies on isolation of active principles from extracts and their bioactivity determinations are to be carried out.

Key words: Smilax zeylanica L., Maceration, Agar well diffusion, Poisoned food technique, DPPH, Ferric reducing

Article Info: Received 02 May, 2018; Review Completed 24 June 2018; Accepted 28 June 2018; Available online 15 July 2018

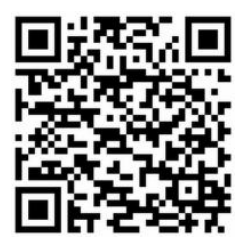

Cite this article as:

Dhanya Shree V.S., Arbin A., Saema Noorain G.K., Sahana B.K., Prashith Kekuda T.R*, Preliminary

phytochemical analysis, antimicrobial and antioxidant activity of Smilax zeylanica L. (Smilacaceae), Journal of

Drug Delivery and Therapeutics. 2018; 8(4)237-243 DOI: http://dx.doi.org/10.22270/jddt.v8i4.1779

Dr. Prashith Kekuda T.R., Department of Microbiology, S.R.N.M.N College of Applied Sciences, N.E.S campus, Balraj Urs Road, Shivamogga-577201, Karnataka, India

\section{INTRODUCTION}

Since time immemorial plants have been widely used as sources of food, construction tools, clothing, spices, dyes and medicine. In various countries across the world, plants are used in primary healthcare either singly or in certain combinations by traditional medicinal practitioners. Countries for e.g. India, China, Bangladesh, Pakistan, Bhutan, Thailand and several European, American and African countries widely employ several plant species as medicine to cure a number of ailments or disorders. Plant based medicines are popular in developing and under-developing countries as the high cost of modern medicines and no access to modern medications to remote places. Plants have also been an indispensable component of traditional medicinal systems namely Ayurveda, Siddha, traditional Chinese medicine (TCM) and Unani. Drugs viz. aspirin, quinine, digitoxin, reserpine, artemisinin, 
diosgenin, ephedrine, codeine, scopolamine, vincristine, vinblastine and several others are from plant origin. ${ }^{1-7}$

The genus Smilax, belonging to the monocotyledon family Smilacaceae, comprises of about 300-350 species. Smilax zeylanica L. (Figure 1) is one of the most important medicinal species of the genus Smilax and is distributed in tropical regions of India and is common in forests. S. zeylanica is a large, scandent, dioecious climbing shrub with woody stem and angular branches. The plant is sometimes armed with prickles. Flowers are greenish-white, dioecious and umbellate. Fruit is a globose berry that turns red on ripening and contains 1-2 seeds. The plant is known by the name Chopachinee in Sanskrit, Chobchini in Hindi, Kaadu hambu taavare/Chennere balli in Kannada, Jangali Ushbaa in Unani and Malai-thaamara in Siddha/Tamil. Leaves are used as vegetable. The plant is used ethnomedicinally for the treatment of various conditions such as venereal diseases, skin diseases, abscesses, boils, psoriasis, rheumatism, swellings, toothache and dysentery. ${ }^{8-12}$

The plant $S$. zeylanica is used as a substitute for Sarsaparilla in many parts of the world. S. zeylanica is a potential alternate source for the Ayurvedic drug Chopachinee (accepted botanical source is S. china L.). The plant contains a myriad of chemicals including chemicals viz. diosgenin, smilagenin, sarsapogenin, $\beta$ sitosterol, hydroxytyrosol, trans-iso-eugenol and squalene. ${ }^{10,13,14}$ The plant is shown to exhibit several bioactivities such as antimicrobial ${ }^{15}$, antioxidant ${ }^{16}$, cytotoxic $^{16}, \quad$ analgesic $^{15}, \quad$ immunomodulatory ${ }^{17}$, antiarthritic ${ }^{17}, \quad$ anthelmintic ${ }^{18}, \quad$ antipyretic ${ }^{19}$, anticonvulsant ${ }^{19}$, antidiabetic ${ }^{20}$, cytoprotective $^{21}$, hepatoprotective ${ }^{22}$, anti-inflammatory ${ }^{23}$, antiepileptic ${ }^{24}$, pesticidal $^{25}$, thrombolytic ${ }^{26}$, and antidepressant-like ${ }^{27}$ activities. The present study was carried out to evaluate antimicrobial and antioxidant activity of methanolic extract of dried and powdered leaves and fruits of $S$. zeylanica.

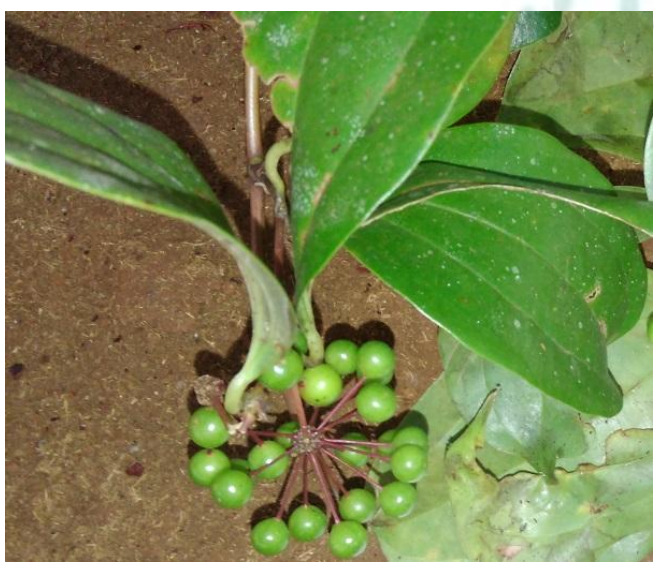

Figure 1: Smilax zeylanica $\mathbf{L}$.

\section{MATERIALS AND METHODS}

\section{Collection and identification of plant}

The plant material was collected at Haniya, Hosanagara taluk, Shivamogga district, Karnataka, India during
January 2018. The plant was identified by Dr. Vinayaka K.S assistant professor, KFGC, Shikaripura, Karnataka.

\section{Extraction and phytochemical analysis}

The leaves and fruits were separated, cleaned well using water, dried under shade and powdered in blender. The extraction of powdered plant material was carried out by maceration process as described in the study carried out by Kekuda et al. ${ }^{28}$ using methanol. The solvents were subjected to evaporation at room temperature. The crude leaf and fruit extracts were subjected to preliminary phytochemical analyses by standard phytochemical tests. ${ }^{29,30,31}$

\section{Antibacterial activity of leaf and fruit extract of $S$. zeylanica}

Bacteria viz. Escherichia coli, Bacillus cereus, Shigella flexneri and Salmonella typhimurium were used to assess their susceptibility to leaf and fruit extracts of $S$. zeylanica. Agar well diffusion method as described in the study of Kekuda et al. ${ }^{\mathbf{2 8}}$ was performed to evaluate antibacterial activity of leaf and fruit extracts. Streptomycin was used as reference antibiotic. Zones of inhibition formed around the wells were measured using a ruler.

\section{Antifungal activity of leaf and fruit extracts of $S$. zeylanica}

Fungi namely Bipolaris sp. and Aspergillus niger isolated from seeds of maize were screened for their susceptibility to extracts of $S$. zeylanica. Antifungal activity of extracts was evaluated by poisoned food technique as described in the study of Kekuda et al. ${ }^{\mathbf{2 8}}$ The mycelial growth inhibition $(\%)$ caused by extracts was determined using the formula:

Mycelial growth inhibition $(\%)=[\mathrm{Dc}-\mathrm{Dt} / \mathrm{Dc}] \times 100$, where 'Dc' and 'Dt' denotes diameter of fungal colonies in control (without extract) and poisoned plates respectively.

\section{DPPH radical scavenging assay}

Various concentrations of the leaf and fruit extracts $(12.50-200 \mu \mathrm{g} / \mathrm{ml})$ of Smilax zeylanica were screened for their antiradical potential by DPPH assay by following the protocol employed by Kekuda et al. ${ }^{28}$ Ascorbic acid was used as reference standard. The absorbance of reaction mixture in each of the tube was measured at $520 \mathrm{~nm}$ and the scavenging of DPPH radicals (\%) was determined using the formula:

Scavenging activity $(\%)=[$ Ac- At / Ac $]$ x 100 where, 'Ac' and 'At' refers to absorbance of DPPH control and absorbance of DPPH and extract/ascorbic acid combination. $\mathrm{IC}_{50}$ value was calculated for extracts as well as ascorbic acid. $\mathrm{IC}_{50}$ value denotes the concentration of extracts/ascorbic acid required to scavenge $50 \%$ of free radicals.

\section{Ferric reducing assay}

Various concentrations of the leaf and fruit extracts $(12.50-200 \mu \mathrm{g} / \mathrm{ml})$ of Smilax zeylanica were screened for their reducing potential by Ferric reducing assay by 
following the protocol employed by Raghavendra et al. ${ }^{32}$ The absorbance of reaction mixture was read at 700nm. Ascorbic acid was used as reference standard. An increase in the absorbance with an increase in concentration of extracts/ascorbic acid indicates reducing potential of extracts.

\section{RESULTS AND DISCUSSION}

Phytochemicals detected in leaf and fruit extracts of S. zeylanica

In this study, we performed maceration process to extract powdered leaf and fruit of $S$. zeylanica. The crude leaf and fruit extracts were subjected to phytochemical analysis by standard phytochemical analysis protocols.

Table 1: Phytochemical groups detected in leaf and fruit extracts of $S$. zeylanica

\begin{tabular}{|l|c|c|}
\hline Phytochemical group & Leaf extract & Fruit extract \\
\hline Alkaloids & + & + \\
\hline Flavonoids & + & + \\
\hline Saponins & + & - \\
\hline Tannins & + & + \\
\hline Glycosides & + & - \\
\hline Triterpenoids & + & + \\
\hline Sterols & + & + \\
\hline Phenolic compounds & + & + \\
\hline \multicolumn{2}{|c|}{ '+' Detected; '-' Not detected } \\
\hline
\end{tabular}

The result of preliminary phytochemical analysis of leaf and fruit extract of $S$. zeylanica is shown in Table 1 . The leaf extract was found to contain all tested phytochemicals, while fruit extract was shown to contain all phytochemicals except saponins and glycosides.

\section{Antibacterial activity of leaf and fruit extracts of $S$. zeylanica}

In this study, the antibacterial effect of extracts of $S$. zeylanica was determined by agar well diffusion assay. The presence of zone of inhibition around the wells was considered positive for antibacterial activity whereas the absence of zone of inhibition was considered as negative. Both leaf and fruit extracts were effective in inhibiting all test bacteria but the inhibitory activity observed was varied. The result of antibacterial activity of leaf and fruit extract of S. zeylanica is shown in Table 2 and Figure 2. Among extracts, marked antibacterial activity was observed in case of leaf extract. Both leaf and fruit extracts inhibited B. cereus and S. typhimurium to highest and least extent respectively. Among gram negative bacteria $S$. flexneri and $S$. typhimurium were inhibited to highest and least extent respectively. DMSO did not cause any inhibitory activity against test bacteria. When compared to extracts, reference antibiotic displayed highest inhibitory activity. In an earlier study, Sarbadhikary et al. ${ }^{33}$ revealed weak antibacterial potential of ethanol extract of leaves against $E$. coli while other bacteria remained unaffected. In another study, Hossain et al. ${ }^{\mathbf{1 5}}$ investigated the potential of methanolic extract of leaves of $S$. zeylanica and showed a concentration dependent inhibitory activity against test bacteria with marked and least inhibitory activity being observed against $S$. paratyphi and E. coli respectively.

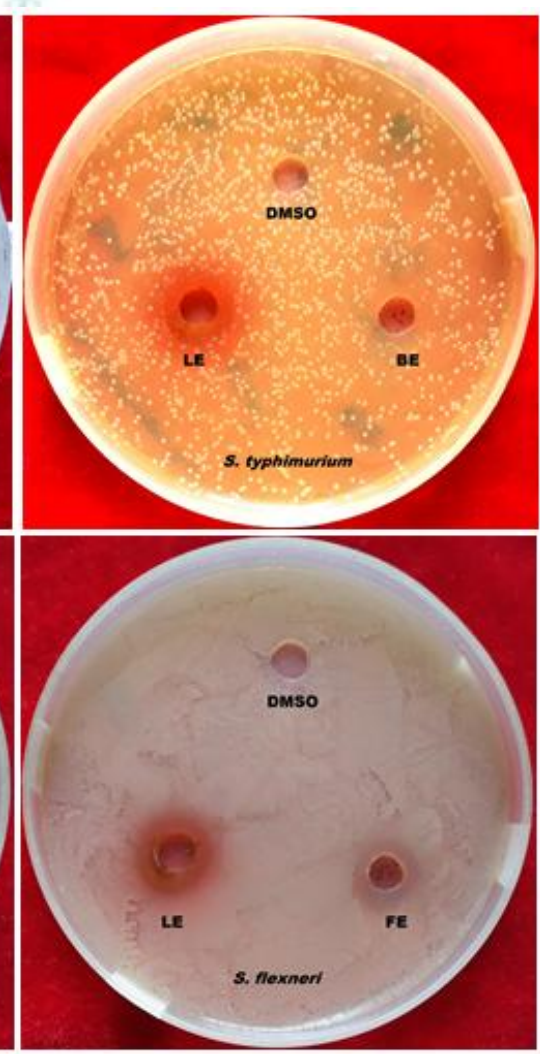

Figure 2: Inhibition of test bacteria by leaf and fruit extracts 
Table 2: Antibacterial activity of leaf and fruit extracts of S. zeylanica

\begin{tabular}{|l|c|c|c|c|}
\hline \multirow{2}{*}{ Test bacteria } & \multicolumn{4}{|c|}{ Zone of inhibition in cm } \\
\cline { 2 - 5 } & Leaf extract & Fruit extract & DMSO & Antibiotic \\
\hline B. cereus & $2.20 \pm 0.00$ & $1.43 \pm 0.05$ & $0.00 \pm 0.00$ & $3.00 \pm 0.00$ \\
\hline S. typhimurium & $1.20 \pm 0.00$ & $1.10 \pm 0.00$ & $0.00 \pm 0.00$ & $3.13 \pm 0.05$ \\
\hline S. flexneri & $1.46 \pm 0.05$ & $1.20 \pm 0.00$ & $0.00 \pm 0.00$ & $3.30 \pm 0.00$ \\
\hline E. coli & $1.30 \pm 0.00$ & $1.20 \pm 0.00$ & $0.00 \pm 0.00$ & $3.53 \pm 0.05$ \\
\hline
\end{tabular}

Antifungal activity of leaf and fruit extracts of $S$. zeylanica

The potential of leaf and fruit extract of S. zeylanica to inhibit seedborne fungi was assessed by poisoned food technique and the result obtained was shown in Table 3 and Figure 3 and 4. Poisoning of medium with the extracts resulted in marked inhibition of mycelial growth of test fungi. Both leaf and fruit extracts inhibited fungal growth to more or less similar extent with leaf extract being more effective than fruit extract. Both extracts were effective in inhibiting the test fungi to $>50 \%$. Among fungi Bipolaris sp. was susceptible to higher extent when compared to A. niger. An earlier study by Saha et al. ${ }^{34}$ revealed the antifungal potential of aqueous and ethanolic leaf extracts of $S$. zeylanica to inhibit fungal pathogens of tea viz. Pestalotiopsis theae, Colletotrichum camelliae, Curvularia eragrostidis and Botryodiplodia theobromae.

Table 6: Antifungal activity of leaf and fruit extracts of $S$. zeylanica

\begin{tabular}{|l|c|c|}
\hline \multirow{2}{*}{ Extract/Control } & \multicolumn{2}{|c|}{$\begin{array}{c}\text { Colony diameter of test fungi } \\
\text { in } \mathbf{~ c m} \text { (\% inhibition) }\end{array}$} \\
\cline { 2 - 3 } & A. niger & Bipolaris sp. \\
\hline Control & $5.70 \pm 0.00$ & $4.8 \pm 0.00$ \\
\hline Leaf extract & $2.43 \pm 0.05$ & $1.6 \pm 0.00$ \\
\hline Fruit extract & $2.50 \pm 0.00$ & $1.96 \pm 0.05$ \\
\hline
\end{tabular}

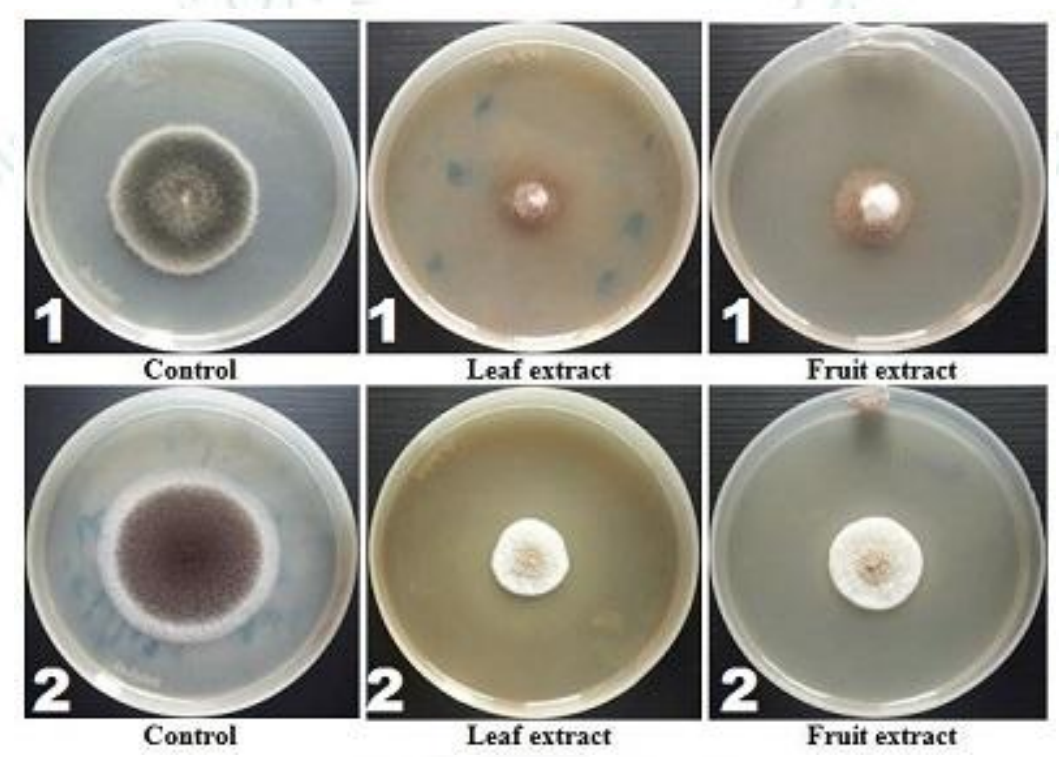

Figure 3: Fungal growth in plates (1- Bipolaris sp.; 2- A. niger)

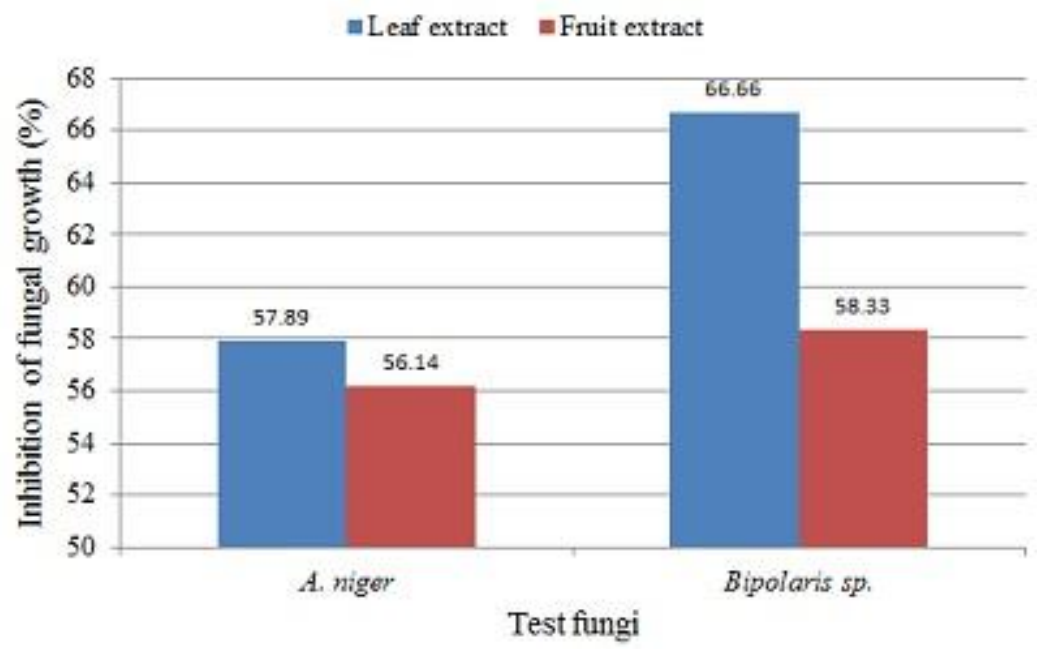

Figure 4: Inhibition of test fungi $(\%)$ by extracts of $S$. zeylanica 
DPPH radical scavenging activity of leaf and fruit extracts of $S$. zeylanica

The potential leaf and fruit extract of $S$. zeylanica to scavenge free radicals was determined by DPPH assay and the result is shown in Figure 5. Both leaf and fruit extracts displayed concentration dependent scavenging of DPPH radicals with highest scavenging activity being shown by leaf extract $\left(\mathrm{IC}_{50}\right.$ value $\left.20.80 \mu \mathrm{g} / \mathrm{ml}\right)$ when compared to fruit extract $\left(\mathrm{IC}_{50}\right.$ value $\left.35.85 \mu \mathrm{g} / \mathrm{ml}\right)$. A scavenging activity of $>50 \%$ was observed at extract concentration of $25 \mu \mathrm{g} / \mathrm{ml}$ and $50 \mu \mathrm{g} / \mathrm{ml}$ in case of leaf extract and fruit extract respectively. At the highest concentration $(200 \mu \mathrm{g} / \mathrm{ml})$, both extracts displayed $>90 \%$ scavenging of DPPH radicals. Hossain et al. ${ }^{15}$ revealed the potential of ethanol extract of the leaves of $S$. zeylanica to scavenge $\mathrm{DPPH}$ radicals with $\mathrm{IC}_{50}$ value of
$30.93 \mu \mathrm{g} / \mathrm{ml}$. Daffodil and Mohan ${ }^{35}$ showed marked scavenging of DPPH radicals by methanol extract of aerial parts of $S$. zeylanica with an $\mathrm{IC}_{50}$ value of $25.77 \mu \mathrm{g} / \mathrm{ml}$. Uddin et al. ${ }^{\mathbf{1 6}}$ revealed dose dependent scavenging of DPPH radicals by methanol and petroleum ether extracts of $S$. zeylanica with $\mathrm{IC}_{50}$ values 29.14 and $72.40 \mu \mathrm{g} / \mathrm{ml}$ respectively. The study of Murali et al. ${ }^{13}$ showed potent scavenging activity of methanolic extract $\left(\mathrm{IC}_{50}\right.$ value $\left.7.6 \mu \mathrm{g} / \mathrm{ml}\right)$ when compared to aqueous extract $\left(\mathrm{IC}_{50}\right.$ values $125 \mu \mathrm{g} / \mathrm{ml}$ ) of roots and rhizomes. In our study, ascorbic acid (reference antioxidant) scavenged DPPH radicals more efficiently $\left(\mathrm{IC}_{50}\right.$ value $6.12 \mu \mathrm{g} / \mathrm{ml}$ ) than leaf and fruit extracts. Although leaf and fruit extracts exhibited lower scavenging potential, it is evident that the plant possesses proton donating potential and thereby can act as primary radical scavengers.

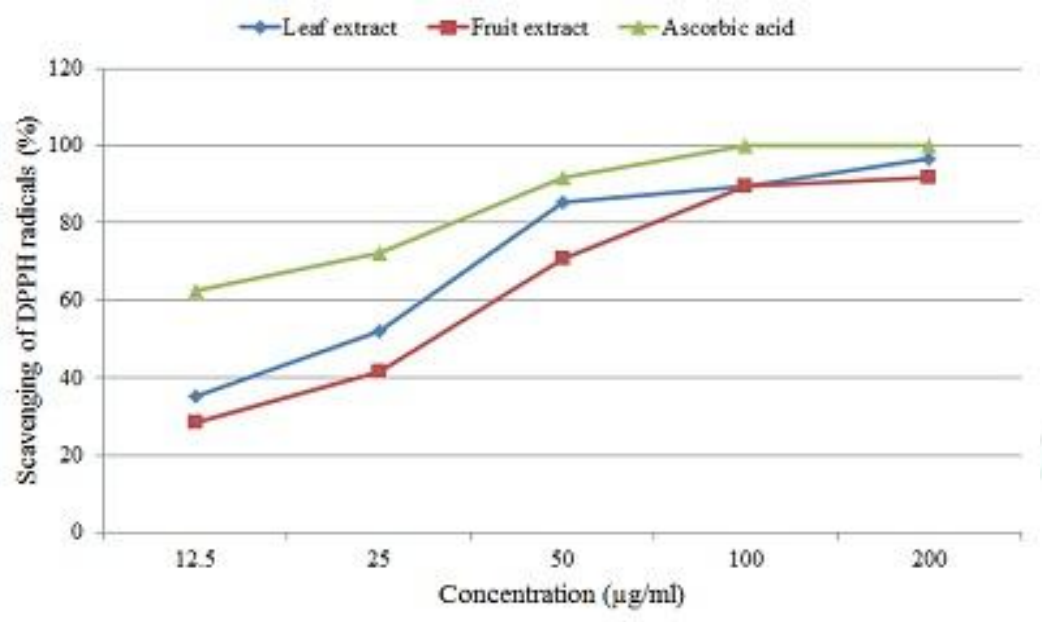

Figure 5: Scavenging of DPPH radicals (\%) by extracts and ascorbic acid

Ferric reducing activity of leaf and fruit extracts of S. zeylanica

The reducing potential of leaf and fruit extract of $S$. zeylanica was determined by ferric reducing activity using ascorbic acid as reference standard. The absorbance of reaction mixtures was measured at $700 \mathrm{~nm}$ and the absorbance found to increase with the increase in the concentration which indicates the reducing potential. The reducing potential of extracts and ascorbic acid was in the order: ascorbic acid > leaf extract $>$ fruit extract (Figure 6). In an earlier study,
Thirugnanasampandan et al. ${ }^{\mathbf{3 6}}$ revealed reducing power of leaf and stem extracts of S. zeylanica. The study of Uddin et al. ${ }^{16}$ revealed marked reducing activity of methanolic extract of stem when compared to aqueous extract of stem. Daffodil and Mohan ${ }^{35}$ showed marked reducing potential of methanol extract of aerial parts of $S$. zeylanica. Although the reducing power of leaf and fruit extracts of $S$. zeylanica observed was lesser when compared to reference standard in this study, it is evident that the extracts possess reductive ability which could serve as electron donors, terminating the radical chain reactions.

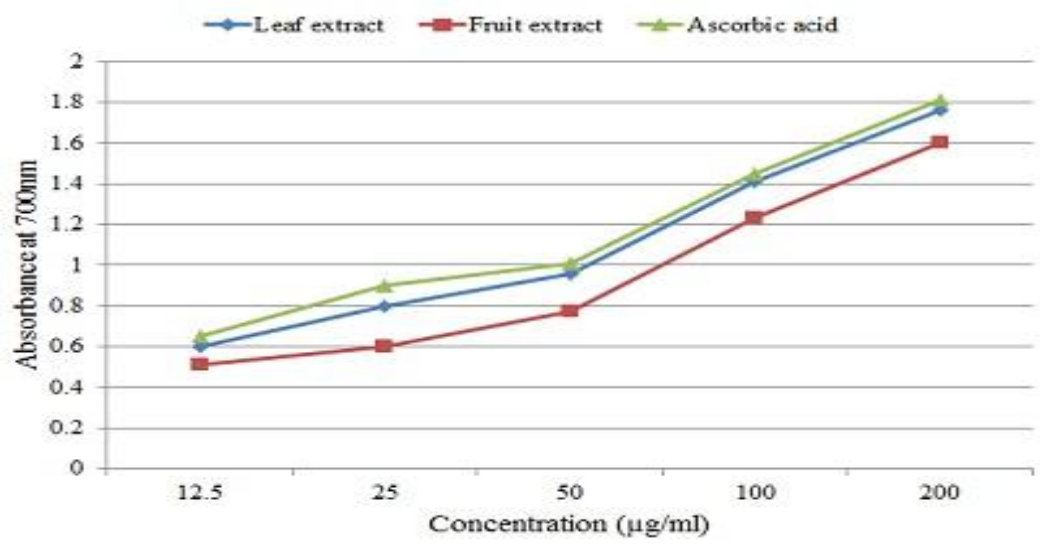

Figure 6: Ferric reducing activity of extracts and ascorbic acid 


\section{CONCLUSIONS}

In the present study, the leaf and fruit extracts of $S$. zeylanica were shown to exhibit antimicrobial and antioxidant activity. Overall, leaf extract displayed marked inhibitory activity against bacteria and fungi, scavenged DPPH radicals more efficiently and exhibited better ferric reducing activity when compared to fruit extract. The plant can be used to develop formulations effective against infectious agents and oxidative damage. Further studies on isolation, characterization and pharmacological potentials of bioactive principles from S. zeylanica are to be carried out.

\section{REFERENCES}

1. Vedavathy $\mathrm{S}$, Scope and importance of traditional medicine, Indian J Tradit Know, 2003; 2(3):236-239.

2. Gurib-Fakim A, Medicinal plants: Traditions of yesterday and drugs of tomorrow, Mol Aspects Med, 2006; 27(1):1-93.

3. Ballabh B, Chaurasia OP, Ahmed Z, Singh SB, Traditional medicinal plants of cold desert Ladakh-used against kidney and urinary disorders, J Ethnopharmacol, 2008; 118(2):331339.

4. Srithi K, Trisonthi C, Wangpakapattanawong P, Balslev H, Medicinal plants used in Hmong women's healthcare in northern Thailand, J Ethnopharmacol, 2012; 139:119-135.

5. Mesfin K, Tekle G, Tesfay T, Ethnobotanical study of traditional medicinal plants used by indigenous people of Gemad district, Northern Ethiopia, Journal of Medicinal Plants Studies, 2013; 1(4):32-37.

6. Vandebroek I, Intercultural health and ethnobotany: How to improve healthcare for underserved and minority communities? J Ethnopharmacol, 2013; 148:746-754.

7. Jaiswal Y, Liang Z, Zhao Z, Botanical drugs in Ayurveda and Traditional Chinese Medicine, J Ethnopharmacol, 2016; 194:245-259.

8. Shetty BV, Kaveriappa KM, Bhat GK, Plant resources of Western Ghats and lowlands of Dakshina Kannada and Udupi districts, Pilikula Nisarga Dhama Society, Mangalore, India, 2002, Pp 58, 211.

9. Khare $\mathrm{CP}$, Indian medicinal plants: An illustrated dictionary, Springer-Verlag Berlin/Heidelberg, 2007, Pp 609.

10. Madhavan V, Hemalatha HT, Gurudeva MR, Yoganarasimhan SN, Pharmacognostical studies on the rhizome and root of Smilax zeylanica Linn. - A potential alternate source for the Ayurvedic drug Chopachinee, Indian J Nat Prod Resour, 2010; 1(3):328-337.

11. Gritto MJ, Aslam A, Nandagopalan V, Ethnomedicinal survey of threatened plants in Pachamalai hills, Tiruchirapalli district, Tamil Nadu, India, Int J Res Ayurveda Pharm, 2012; 3(6):844-846.

12. Luitel DR, Rokaya MB, Timsina B, Munzbergova Z, Medicinal plants used by the Tamang community in the Makawanpur district of central Nepal, J Ethnobiol Ethnomed, 2014; 10:5.

13. Murali A, Ashok $\mathrm{P}$, Madhavan $\mathrm{V}$, In vitro antioxidant activity and HPTLC studies on the roots and rhizomes of Smilax zeylanica L. (Smilacaceae), Int J Pharm Pharm Sci, 2011; 3(1):192-195.

14. Rajesh V, Perumal P, In-vitro cytoprotective activity of Smilax zeylanica leaves against hydrogen peroxide induced oxidative stress in L-132 and BRL 3A cells, Orient Pharm Exp Med, 2014; 14(3):255-268.

15. Hossain AM, Saha S, Asadujjaman M, Kahan AS, Analgesic, antioxidant and antibacterial activity of Smilax zeylanica Linn. (family-Smilacaceae), Pharmacologyonline, 2013; 1:244-250.

16. Uddin MN, Ahmed T, Pathan S, Al-Amin MM, Rana MS, Antioxidant and cytotoxic activity of stems of Smilax

\section{ACKNOWLEDGEMENTS}

Authors thank HOD, Department of Microbiology and Principal, S.R.N.M.N College of Applied Sciences, Shivamogga and N.E.S, Shivamogga for providing facilities and moral encouragement. Authors also express sincere gratitude to Dr. Vinayaka K.S, Principal, KFGC, Shikaripura for assisting in collection and identification of the plant.

\section{Sources of Support: None}

Conflicts of Interest: None declared

zeylanica in vitro, J Basic Clin Physiol Pharmacol, 2015; 26(5):453-463.

17. Babu VP, Ashwini T, Krishna VM, Raju GM, Immunomodulatory and antiarthritic activities of Smilax zeylanica, Int J Phytomed, 2017; 8:123-131.

18. Jena PK, Nayak BS, Dinda SC, Ellaiah P, Investigation on phytochemicals, anthelmintic and analgesic activities of Smilax zeylanica Linn. leafy extracts, Asian J Chem, 2011; 23(10):4307-4310.

19. Jena PK, Dinda SC, Ellaiah P, Phytochemical investigation and simultaneous study on antipyretic, anticonvulsant activity of different leafy extracts of Smilax zeylanica Linn, Orient Pharm Exp Med, 2012; 12:123-127.

20. Jena PK, Dinda SC, Ellaiah P, Antidiabetic activity of various leafy extracts of Smilax zeylanica Linn in streptozotocin induced diabetic rats, Asian J Chem, 2012; 24(10):4825-4826.

21. Rajesh V, Perumal P, Cytoprotective effect of Smilax zeylanica Linn. leaves against Benzo[a]pyrene induced lung cancer with reference to lipid peroxidation and antioxidant system in Swiss albino mice, Orient Pharm Exp Med, 2013; 13:267-277.

22. Murali A, Ashok P, Madhavan V, Study of hepatoprotective activity of methanol extract of Smilax zeylanica L. leaf against carbontetrachloride induced hepatic damage in rats, MSRUAS-SASTech Journal, 2014; 13(2):25-28.

23. Nithyamala I, Ayyasamy S, Pitchiahkumar M, Kumar A, Velapandian V, Evaluation of analgesic and antiinflammatory activity of Siddha drug Karuvilanchi ver choornam (root powder of Smilax zeylanica Linn) in rodents, IOSR Journal of Pharmacy and Biological Sciences, 2013; 6(1):6-11.

24. Madhavan V, Hemalatha HT, Murali A, Yoganarasimhan $\mathrm{SN}$, Antiepileptic activity of alcohol and aqueous extracts of roots and rhizomes of Smilax zeylanica Linn, Pharmacologyonline, 2008; 3:263-272.

25. Bari MA, Islam W, Khan AR, Pesticidal activity of Smilax zeylanica L. extracts on Cryptolestes pusillus (Schon.) (Coleoptera: Cucujidae), Journal of Bangladesh Academy of Sciences, 2010; 34(2):205-208.

26. Hossen MSM, Khan IN, Sarkar MMI, Jahid MA, Assessment of thrombolytic activity of five Bangladeshi medicinal plants: Potential source for thrombolytic compounds, International Blood Research and Reviews, 2014; 2(6):262269.

27. Ahemad RS, Venkataraman S, Ahmad F, Ibrahim M, Antidepressant-like activity of Smilax zeylanica Linn in behavioral despair tests in mice, European Journal of Pharmaceutical and Medical Research, 2016, 3(12), 335-341.

28. Kekuda PTR, Raghavendra HL, Shilpa M, Pushpavathi D, Petkar T, Siddiqha A, Antimicrobial, antiradical and insecticidal activity of Gardenia gummifera L.f. (Rubiaceae), Int J Pharm Pharm Sci, 2017; 9(10):265-272. 
29. Tiwari P, Kumar B, Kaur M, Kaur G, Kaur H, Phytochemical screening and extraction: A review, Internationale Pharmaceutica Sciencia, 2011; 1(1):98-106.

30. Ajayi IA, Ajibade O, Oderinde RA, Preliminary phytochemical analysis of some plant seeds, Res J Chem Sci, 2011; 1(3):58-62.

31. Santhi K, Sengottuvel R, Qualitative and quantitative phytochemical analysis of Moringa concanensis Nimmo, Int J Curr Microbiol App Sci, 2016; 5(1):633-640.

32. Raghavendra HL, Kekuda PTR, Akarsh S, Ranjitha MC, Ashwini HS, Phytochemical analysis, antimicrobial and antioxidant activities of different parts of Pleocaulus sessilis (Nees) Bremek (Acanthaceae), Int J Green Pharm, 2017; 11(2):98-107.
33. Sarbadhikary SB, Bhowmik S, Datta BK, Mandal NC, Antimicrobial and antioxidant activity of leaf extracts of two indigenous Angiosperm species of Tripura, Int J Curr Microbiol App Sci, 2015; 4(8):643-655.

34. Saha D, Dasgupta S, Saha A, Antifungal activity of some plant extracts against fungal pathogens of tea (Camellia sinensis), Pharm Biol, 2005; 43(1):87-91.

35. Daffodil ED, Mohan VR, In vitro antioxidative profiling of Smilax zeylanica aerial parts, Int J Pharm Sci Rev Res, 2017; 42(1):85-90

36. Thirugnanasampandan $\mathrm{R}$, Mutharaiah VN, Bai NV, In vitro propagation and free radical studies of Smilax zeylanica Vent, Afr J Biotechnol, 2009; 8(3):395-400. 